\title{
Modeling the Dynamic Relationship between Food Crop Output Volatility and Its Determinants in Nigeria
}

\author{
S. B. Akpan ${ }^{1}$, E. J. Udoh ${ }^{2}$ \& A. A. Umoren ${ }^{2}$ \\ ${ }^{1}$ Department of Agricultural Economics and Resource Management, AkwaIbom State University, Nigeria \\ ${ }^{2}$ Department of Agricultural Economics and Extension, University of Uyo, AkwaIbom State, Nigeria \\ Correspondence: E. J. Udoh, Department of Agricultural Economics and Extension, University of Uyo, \\ AkwaIbom State, Nigeria. E-mail: ej_udoh@hotmail.com
}

Received: March 6, 2012 Accepted: March 23, 2012 Online Published: June 29, 2012

doi:10.5539/jas.v4n8p36 URL: http://dx.doi.org/10.5539/jas.v4n8p36

\begin{abstract}
The study modeled the short run and long run food crop output volatility equations in Nigeria. Time series data derived from the FAO data base for Nigeria and publications of the CBN covering the period 1961 to 2010 was used in the study. Unit root test conducted on the specified time series shows that all series were integrated of order one at $1 \%$ probability level. The $\operatorname{GARCH}(1,1)$ model was used to generate the food crop output volatility for the selected food crops (i.e. rice, maize, sorghum, cassava and yam). The short-run and long-run elastic cities of food crop output volatility with respect to specify explanatory variables were determined using the techniques of co-integration and error correction model estimation based on the OLS estimation. The empirical results revealed that inflation rate, per capita real GDP, loan guaranteed by ACGSF in the food crop sub sector, harvested area of land for food crop and liberalization policy era had mixed influence on food crop output volatility both in the short and long run periods in Nigeria. The result also showed that harvested area of land for the selected food crop was the most important factor that affects food crop volatility in the country. In addition, food crop volatility show an average declines pattern in the liberalization policy period. The study however advocated for appropriate short and long term policy packages that should addressed appropriately the identified significant macroeconomic shifters of food crop output volatility in the country. Also attention should be directed towards improving the quality of land allocated to food crop sub sector. Furthermore, agricultural policies in the liberalization policy package should be design in the short term basis and use as a means for altering food crop output in Nigeria.
\end{abstract}

Keyword: food, crop, volatility, GARCH, inflation, land, policies, loan

\section{Introduction}

Nigeria is an agrarian society despite the dominant contribution of the petroleum sector to the country's GDP (Sanusi, 2010; Izuchukwu, 2011). About 60-70 percent of the population is engaged in agricultural production and other agro -businesses (Nigerian National planning Commission, 2004; Chigbu, 2005). In 2006 for instance, agriculture's contribution was about $32.1 \%$ of the Gross Domestic Product (GDP), and about $40.3 \%$ in the period 2001 to 2009 (Sanusi, 2010). Despites the contribution of the agricultural sector to the economic development of Nigeria, the growth rate in the sector has been undulating; and mostly attributed to the lopped sided agricultural policies, soil infertility problems, over dependency on rain-fed agriculture, instability in macroeconomic variables and increasing food import (Federal Republic of Nigeria, 2000; Jeter, 2004).

Government realizing the significant of agricultural sector has severally intervened to regulate activities in the sector. During the post independence era, the source of intervention was mainly through the Development Plans and annual budgets (Akpan, 2010). Development Plans and annual budgets were used by government to provide funds for support to agriculture in line with the import substitution policy framework of the federal government. These funds were hardly enough to support the sector's programs due to increasing corruption tendencies among government officials, institutional and policy mis-specification among others (Sanusi, 2010). Agricultural related programmes and policies were initiated and implemented following the declining roles of agriculture to economic growth in the country. Some of the development programmes and policies instituted to stimulate agricultural development in Nigeria include; The Agricultural Development Project (ADP) conceptualized in 1975 and was mandated to provide decentralized opportunities and resources in agriculture to small holder farmers; Operation Feed the Nation (OFN) set up in 1976, to provide sufficient food for all Nigerian; 
Agricultural Credit Guarantee Scheme Fund (ACGSF) established in 1978 to facilitate agricultural credit to farmers; Green Revolution (GR) was implemented in 1979 to encourage the production of sufficient food and improved nutrition to all Nigerian; Nigerian Agricultural Insurance Cooperation established in 1987 to provide sufficient insurance cover for agricultural production businesses; Strategic Grain Reserves was established in 1988 to mop up excess grains production and make such available locally in time of scarcity; People Bank of Nigeria was set up in 1989 to provide credit at low interest rate to small scale entrepreneurs to encourage micro-enterprises; National Agricultural Land Development Authority (NALDA) was set up in 1992 to provide public support for land development, promote and support optimum utilization of rural resources and support economic size farm holdings; and Nigerian Agricultural Cooperative and Rural Development Bank found in 2000 to provide credit for production, processing and marketing of agricultural products among others (Udoh \& Akpan, 2007; Ukoha, 2007; Akpan \& Udoh, 2009a; Akpan \& Udoh, 2009b).

On the other hand, government has employed several monetary policy measures to increase agricultural production and at the same time curb inflation. Direct monetary control techniques were employed in the pre-SAP period. The major tools of monetary policy were administered interest and exchange rates, prescription of cash reserve requirements, selective credit controls and credit ceilings among others (Anyanwu et al., 1997). In the SAP period (1986-1993), indirect monetary measures were used which included the deregulation of interest rates and increase in commercial banks cash reserve among others. In the post-SAP period (1994 to date), administratively controlled measures were first adopted in 1994 and were abandoned in 1995 for policy of guided deregulation. Banks became directly involved in equity funding and management of small-scale enterprises. Apart from monetary policies, the government has also employed some fiscal policy measures to ensure full employment of resources in the agricultural sector. The measures include tax holidays, tariff protection, import duty relief, bans on certain food imports and the provision of credit facilities.

Despite these incentives and policies, the shortfall in domestic food production rose from $0.53 \mathrm{Mt}$ in 1994 to 3.13 Mt in 1998 and 6.52 Mt in 2001. As a consequence, the country resorted to massive importation of food items thereby increasing food import bills from $\$ 2.09 \mathrm{~m}$ in 1994 to $\$ 12.71 \mathrm{~m}$ in 1998 and $\$ 24.36 \mathrm{~m}$ in 2001 (Table 1). Insufficient domestic food production turns Nigeria into a net food importer especially the grains.

Table 1. Food production, demand, shortfalls and imports bill of Nigeria

\begin{tabular}{lcccccccc}
\hline Description & 1994 & 1995 & 1996 & 1997 & 1998 & 1999 & 2000 & 2001 \\
\hline Food production (Mt) & 86.70 & 89.25 & 93.35 & 95.64 & 98.74 & 100.41 & 102.12 & 103.86 \\
Food demand (Mt) & 87.23 & 89.55 & 96.26 & 99.03 & 101.87 & 104.63 & 107.46 & 110.37 \\
Shortfall (Mt) & 0.53 & 0.30 & 2.91 & 3.39 & 3.13 & 4.22 & 5.34 & 6.51 \\
Food import (Mt) & 0.67 & 0.58 & 2.95 & 3.47 & 3.24 & 4.48 & 5.59 & 6.91 \\
Food import Bill (Ab) & 16.77 & 88.35 & 75.95 & 100.64 & 102.16 & 103.49 & 120.05 & 195.81 \\
Food import Bill (US \$b) & 2.09 & 10.99 & 9.45 & 12.52 & 12.71 & 12.88 & 14.35 & 24.36 \\
\hline
\end{tabular}

Source: National bureau of statistic, review of the Nigeria economy, various Issues; CBN, statistical bulletin and annual report (various issues)

It is observed that several agricultural and economic policies as well as programmes implemented by the federal government of Nigeria accompany food crop output variability. For example, yam output volatility decreased from $35.6 \%$ in the period 1971-1976, fluctuating over the years to $23.90 \%$ in $1980-1985$, and then increased to 43.20\% in 1986-1989 (Garba, 2000). Although, sustained growth is a rare achievement, especially in the sub Saharan Africa (Malik \& Jonathan, 2009). Agénor et al., (2000) relates output volatility to policy inconsistency in developing countries. Essang (1973) and Muroi (1989) also correlate food crop output volatility in Nigeria to poor policy on technology and land use Acts. In a similar way, several empirical evidences relate output volatility to inflation rate. For instance, Fountas et al. (2006), Andreou et al. (2008), Narayan et al., (2009), and Chapsa et al. (2011) found evidence of negative effect of inflation on output volatility. Coulson and Robins (1985), however reported positive effect while Jansen (1989) attested to neutral relationship between the variables

Surprisingly, the direct impact of agricultural policies on crop output volatility in Nigeria has received limited attention in the empirical literature; in spite that increased in output was among the primary goals of most of the 
past and present agricultural policies (Ukoha, 2007; Udoh \& Sunday, 2007; Akpan \& Udoh, 2009). However, Akpan (2012) provided a comprehensive study on food crop output volatility behavior in different agricultural policy programme periods in Nigeria covering the period 1961 to 2009 . He used GARCH $(1,1)$ model to generate respective food crop output volatility. His results revealed that Pre-Operation Feed the Nation period (1961-1976) and Structural Adjustment Programme (1986-1993) period were the most volatile sub periods for most food crop outputs in the country. Whereas, food crop outputs were most stable during the Operation Feed the Nation period (1976-1979) and Green Revolution period (1980-1985). Also, the mean food crop outputs showed a progressive growth rate across the policy programme periods since 1961, and were best during Post Structural Adjustment period (1994-2009). Jordaan et al., (2007) in South Africa, used standard error of the ARIMA process as the measure of volatility of prices of wheat and soybeans and found that volatility in the two crops was constant over time.

The study therefore believes that, if food crop output fluctuation assumes a rising trend that is significant enough to offset domestic demand volatility, then other policy objectives could be attain simultaneously citeris paribus. The knowledge of output volatility relative to any agricultural policy under quasi market - oriented economy like Nigeria is imperative. Food crop output volatility is an indispensable input to both agricultural policy makers and farmers especially on the decision making process. Increase positive crop volatility could be an indication of the stimulating effect of the existing agricultural policy. But others argue that increase output volatility could increase farmers' income risks and uncertainties due to anticipating price volatility (Young \& Shields, 1996; Ukoha, 2007). Resource allocation efficiency among farmers could be enhanced as the result of increase in the output volatility in a given policy regime provided there is a guarantee minimum price for output of crops. Output volatility is important for promoting sustainable development policies and private investment decisions in farming and farm product marketing (Heifner \& Kinoshita, 1994). Therefore, due to the important of food crop output volatility and its mixed correlation with other variables in the economy, the study specifically established the econometric relationship among food crop (rice, maize, yam and cassava) volatility and agricultural policy periods, farm related factor as well some macroeconomic variables in Nigeria.

\section{Measuring Food Crop Output Volatility}

The GARCH model of the form GARCH $(p, q)_{t}$ for which $\mathrm{p}, \mathrm{q}=1$ was specified and used to generate volatility for the food crop outputs in Nigeria. It was found that simple $\operatorname{GARCH}(1,1)$ process as specify in equation (2) provided a good approximation of the data generating process for sorghum, cassava, and rice as well as yam enterprises. However, Taylor and Schwert's GARCH(1,1) as specify in equation (3) was appropriate for maize enterprise.The annual food crop output was assumed to follow a primitive first-order autoregressive (AR) (1) process as follows,

$$
\begin{gathered}
\Delta \log \left(Y_{t}\right)=\lambda_{0}+\lambda_{1} \Delta \log \left(Y_{t-1}\right)+v_{1} \\
\text { Where } v \sim \operatorname{iid}(0,1) .
\end{gathered}
$$

Where $\left(Y_{t}\right)$ is the output of food crops (Yam, Cassava, Maize, Rice and Sorghum) and $v$ is the stochastic disturbance term. The general assumption is that disturbances from Equation (1) are not auto correlated. Therefore, equation 1 is the mean equation from which the GARCH process was derived as shown in equations (2) and (3).

$$
\begin{aligned}
& \operatorname{Vol}_{t}=\delta+\alpha \sum \varepsilon^{2}{ }_{t-1}+\beta \sum h_{t-1} \\
& \mathrm{Vol}_{\mathrm{t}}=\delta+\alpha \sum / \varepsilon^{2}{ }_{t-1} /+\beta \sum h_{t-1}
\end{aligned}
$$

Equation (2) shows that the conditional variance of the error term in equation (1) which is a proxy of output volatility $\left(\right.$ Vol $\left._{t}\right)$ at period ' $\mathrm{t}$ ' is explained by the past shocks or square of error term (ARCH term i.e. $\varepsilon_{t-1}$ ) as describe in equation (1) and past variance or volatility term (the GARCH term i.e. $h_{t-1}$ ). For equation (2) and (3) to be stationary, $\delta>0, \alpha \geq 0, \beta \geq 0$ and the persistent of volatility shocks $(\alpha+\beta)$ should be less than 1 . As the sum of $\alpha$ and $\beta$ becomes close to unity, shocks become much more persistent (Bollerslev, 1986). The inclusion of lagged conditional variances captures some sort of adaptive learning mechanism (Bollerslev, 1986; Crain \& Lee, 1996; Yang et al., 2001). The estimates of equation (2) and (3) were used to test the persistence of volatility in the selected food crop in the study period. The GARCH approach has been used to study volatility in variables by many researchers (Moledina et al., 2003; Ghebrechristos, 2004 \& Jordaan et al., 2007 in South Africa). The model relied on the assumption of homoscedasticity - instead of considering heteroscedasticity as a problem to be solved. The GARCH approach essentially generalizes the purely autoregressive ARCH model to an autoregressive moving average model. The weights on past squared residuals are assumed to decline 
geometrically at a rate to be estimated from the data (Engle, 2004). Engle (2004) goes on to state that the GARCH forecast variance is a weighted average of three different variance forecasts: i.e. one is a constant variance that corresponds to the long-run average, the second is the forecast that was made in the previous period, and the third is the new information that was not available when the previous forecast was made. The weights on these three forecasts determine how rapidly the variance changes with new information and how rapidly it reverts to its long-run mean. It is for these reasons that the GARCH approach makes better use than other methods (i.e. standard deviation, the coefficient of variation, the Black-Scholes-Merton model, the percentage range, the average percentage change, the moving average, and the Coppock index) of the information on volatility contained in the time series.

\section{Methodology}

\subsection{Study Area and Data Source}

The study was conducted in Nigeria; the country is situated on the Gulf of Guinea in the sub Saharan Africa. Data used in the study were from FAO crop production database for Nigeria and publications of the Central Bank of Nigeria (CBN) and National Bureau of Statistics. The data covered the period 1961 to 2010.

\subsection{Analytical Techniques}

To investigate factors that influence output volatility of food crop in Nigeria generated in equation 1 , the following empirical model was specified based on the objective of the study.

$$
\text { Vol }_{t}=\delta_{0}+\delta_{1} \text { LnPGDP }_{t}+\delta_{2} \text { LnINFL }_{t}+\delta_{3} \text { LnLoan }_{t}+\delta_{4} \text { LnHect }_{t}+\delta_{5} \text { Dummy } U_{t}
$$

Where;

$V O L_{t}=$ respective food crop output volatility generated from the GARCH models (sorghum, maize, rice, cassava and yam)

$P G D P_{t}=$ real per capita GDP as a proxy of aggregate demand shock ( $\#$ m/person)

$\operatorname{Loan}_{t}=$ amount of loan guaranteed by Agricultural Credit Guarantee Scheme fund in the food crop sub-sector from ( $\mathrm{Am}$ ). (Note from 1961 to 1977 the scheme did not exist, so we used a constant 1 during this period)

$I N F L_{t}=$ annual inflation rate in Nigeria (\%)

Hect $=$ annual harvested hectare of respective food crop specified

$D=$ dummy variable which takes the value 1 during liberalization policy period (1986- 2010), and zero otherwise (1961- 1985).

$U_{t}=$ stochastic error term and $U_{t} \sim i i d\left(0, \delta^{2} u\right)$.

The general specification of the ECM estimated for the food crop output volatility in Nigeria is described as follows:

$$
\Delta \operatorname{Vol}_{t}=\delta_{0}+\delta_{1} \Delta \operatorname{LnVol}_{t-1}+\delta_{2} \Delta L n P G D P_{t-1}+\delta_{3} \Delta \operatorname{LnINFL}_{t-1}+\delta_{4} \Delta \operatorname{LnLoan}_{t-1}+\delta_{5} \Delta \operatorname{LnHect}_{t-2}+\delta_{6} \text { Dummy } \delta_{7} E C M_{t-1}+U_{t}
$$

The variables are as defined previously in equation (4).

Following the Granger Representation Theorem, we specify the ECM model for the cointegrating series in the study. The primary reason for estimating the ECM model was to capture the dynamics in the food crop output volatility equations in Nigeria in the short-run and identify the speed of adjustment as a response to departures from the long-run equilibrium. To obtain a parsimonious dynamic ECM for the food crop output volatility in Nigeria, the study adopts Hendry's (1995) approach in which an over parameterized ECM model was initially estimated and then gradually reduce by eliminating insignificant lag variables until a more interpretable and parsimonious ECM model was obtained. The result of the exercise is presented in Table 6.

\section{Results and Discussion}

The estimates of the GARCH models are presented in Table 2. The time varying pattern of the output volatility was confirmed because at least one of the coefficients of the GARCH models was significant for all the 5 food crop enterprises. 
Table 2. The GARCH model estimates for equation 2 and 3

\begin{tabular}{llllll}
\hline Variable & \multicolumn{1}{c}{ Cassava } & \multicolumn{1}{c}{ Sorghum } & \multicolumn{1}{c}{ Rice } & \multicolumn{1}{c}{ Maize } & \multicolumn{1}{c}{ Yam } \\
\hline $\begin{array}{l}\text { Mean Equation } \\
\text { Constant }\end{array}$ & $9.32(5.21)^{* * *}$ & $8.52(18.7)^{* * *}$ & $7.29(5.91)^{* * *}$ & $8.55(15.7)^{* * *}$ & $8.80(9.40)^{* * *}$ \\
& & & & & \\
Variance equation & & & & & \\
Constant & $0.003(1.24)$ & $0.009(0.95)$ & $0.02(0.90)$ & $0.06(4.60)^{* * *}$ & $0.06(1.57)$ \\
ARCH $(\alpha)$ & $0.99(3.45)^{* * *}$ & $0.60(2.21)^{* *}$ & $0.96(2.90)^{* *}$ & $0.59(9.82)^{* * *}$ & $0.76(6.27)^{* * *}$ \\
GARCH $(\beta)$ & $0.00(1.66)^{*}$ & $0.31(1.86)^{*}$ & $0.01(0.01)$ & $0.33(2.96)^{* * *}$ & $0.19(2.47)^{* *}$ \\
& & & & & \\
Persistence & 0.99 & 0.91 & 0.97 & 0.92 & 0.95 \\
AIC & 46.11 & 43.91 & 129.85 & 85.13 & 85.05 \\
HQC & 49.70 & 47.49 & 133.43 & 88.00 & 87.94 \\
SBC & 55.57 & 53.37 & 139.31 & 92.69 & 92.64 \\
Loglik & -18.06 & -16.96 & -59.92 & -38.56 & -38.54 \\
\hline
\end{tabular}

Source: Asterisks *, ${ }^{* *}$ and $* * *$ represent $10 \%, 5 \%$ and $1 \%$ significance levels respectively. Variables are as defined in equation (2) and (3).

The sum of $\alpha$ and $\beta$ measures the persistence of food crop output volatility. In all the 5 crop enterprises the sum of $\alpha$ and $\beta$ was close to but less than unity, thus implying the persistent volatility effect of shocks on food crop output volatility in Nigeria. The GARCH parameters were significant at various levels of probability for the crop enterprises. Exception of rice enterprise, the $\beta$ coefficient was significant in cassava, sorghum, maize and yam enterprises.

\subsection{Unit Root Test for Variables Used in the Analysis}

To ascertain the stationarity of the variables specify in the model, the standard Augmented Dickey - Fuller test and KPSS (Kwiatkowski, Phillips, Schmidt and Shin) tests were performed. Test statistics for each variable in levels and first differences are presented in Table 2.

Table 3. Result of the unit root test for variables used in the analysis

\begin{tabular}{|c|c|c|c|c|c|c|c|c|c|c|c|c|}
\hline \multirow[b]{3}{*}{$\begin{array}{l}\text { Logged } \\
\text { Variables }\end{array}$} & \multicolumn{6}{|c|}{ Augmented Dicker Fuller Test for unit root } & \multicolumn{6}{|c|}{ KPSS Test for unit root } \\
\hline & \multicolumn{3}{|c|}{ With Trend } & \multicolumn{3}{|c|}{ Without Trend } & \multicolumn{3}{|c|}{ With Trend } & \multicolumn{3}{|c|}{ Without Trend } \\
\hline & Level & $\begin{array}{l}\text { 1st } \\
\text { diff. }\end{array}$ & OT & Level & $\begin{array}{l}\text { 1st } \\
\text { diff. }\end{array}$ & OT & Level & $\begin{array}{l}\text { 1st } \\
\text { diff. }\end{array}$ & OT & Level & $\begin{array}{l}1 \text { st } \\
\text { diff. }\end{array}$ & OT \\
\hline VCas & -2.289 & $-6.08 *$ & 1(1) & -1.641 & $-5.65^{*}$ & 1(1) & $0.309 *$ & 0.064 & 1(1) & 1.023 & 0.642 & 1(1) \\
\hline VSorg & -2.389 & $-7.52 *$ & 1(1) & -2.220 & $-7.56^{*}$ & 1(1) & $0.261 *$ & 0.078 & 1(1) & $0.795 *$ & 0.141 & $1(1)$ \\
\hline VRic & -4.115 & $-16.5^{*}$ & 1(1) & -2.800 & $-16.2^{*}$ & 1(1) & $0.266^{*}$ & 0.078 & 1(1) & $0.822 *$ & 0.078 & 1(1) \\
\hline VMaz & -3.528 & $-12.5^{*}$ & 1(1) & -2.428 & $-12.7 *$ & 1(1) & $0.243^{*}$ & 0.064 & 1(1) & $0.842 *$ & 0.066 & 1(1) \\
\hline VYam & -3.925 & $-11.3^{*}$ & 1(1) & -0.088 & $-10.8^{*}$ & 1(1) & $0.308^{*}$ & 0.096 & 1(1) & $1.000^{*}$ & 0.563 & $1(1)$ \\
\hline HaCas & -2.127 & $-7.79 *$ & 1(1) & -0.264 & $-7.82 *$ & 1(1) & 0.189 & 0.087 & $1(0)$ & $1.242 *$ & 0.105 & $1(1)$ \\
\hline HaSorg & -2.715 & $-9.17 *$ & 1(1) & -2.497 & $-9.28 *$ & 1(1) & $0.214 *$ & 0.088 & 1(1) & 0.485 & 0.084 & $1(0)$ \\
\hline HaRic & -2.633 & $-9.94 *$ & 1(1) & -1.053 & $-10.05^{*}$ & 1(1) & 0.139 & 0.073 & $1(0)$ & $1.285^{*}$ & 0.098 & $1(1)$ \\
\hline HaMaz & -1.622 & $-6.53 *$ & 1(1) & -0.844 & $-6.60 *$ & 1(1) & 0.142 & 0.112 & $1(0)$ & 0.810 & 0.126 & $1(1)$ \\
\hline HaYam & -1.737 & $-6.52 *$ & 1(1) & -0.941 & $-6.59 *$ & 1(1) & 0.180 & 0.074 & $1(0)$ & $1.089 *$ & 0.072 & $1(1)$ \\
\hline PGDP & -1.957 & $-5.85^{*}$ & 1(1) & -0.772 & $-5.91 *$ & 1(1) & 0.131 & 0.094 & $1(0)$ & $1.086^{*}$ & 0.095 & $1(1)$ \\
\hline INFL & -3.054 & $-6.89 *$ & 1(1) & -2.577 & $-6.97 *$ & 1(1) & $0.216^{*}$ & 0.058 & 1(1) & 0.625 & 0.061 & $1(0)$ \\
\hline Loan & -2.106 & $-6.33 *$ & 1(1) & -0.757 & $-6.40 *$ & 1(1) & $0.318^{*}$ & 0.075 & 1(1) & $1.224 *$ & 0.075 & $1(1)$ \\
\hline \multicolumn{13}{|c|}{ fined at $1 \%$ leve } \\
\hline $1 \%$ & -4.16 & -4.16 & & -3.57 & -3.57 & & 0.213 & 0.213 & & 0.724 & 0.723 & \\
\hline
\end{tabular}

Note: OT means order of integration. Critical value (CV) is defined at $1 \%$ significant level and asterisk * represents 1\% significance level. VCas, VSorg, VRic, VMaz, and VYam are volatility of respective crops. HaSorg, HaCas, HaRic, HaMaz and HaYam are harvested hectares of respective crops. Other variables are as defined in equations (4). 
The test result revealed that at levels, all variables (in log) used in this study were non-stationary; but stationary at first difference and are therefore integrated of order $1\{$ i.e. 1 (1) $\}$. We cannot therefore specify equation (4) in the levels of the variables without the risk of obtaining spurious regression.

The existence of cointegration between the food crop volatility and the explanatory variables was determined. The Engle-Granger two-step procedure was adopted to test for cointegration (Gujarati, 2004). The order of integration of the residuals generated from equation (4) for each of the 5 crop enterprises were evaluated for their order of integration and were found significant. Consequently, the existence of cointegration with respect to the regressands and regressors in each of the 5 crop enterprise equation (i.e. equation 4 ) could not be rejected. Table 4 presents the results of the long-run(static) regression, while Table 5 shows the order of integration of the residuals generated from static the models.

Table 4. Cointegration or Long-run equation of food crop output volatility in Nigeria

\begin{tabular}{llllll}
\hline Variables & Cassava & Sorghum & Rice & Maize & Yam \\
\hline Constant & $-9.36(-9.54)^{* * *}$ & $-0.45(-0.61)$ & $1.85(0.62)$ & $10.87(3.72)$ & $-9.63(-5.12)^{* * *}$ \\
LnPGDPt & $-0.004(-0.07)$ & $-0.07(-2.40)^{* *}$ & $0.22(0.98)$ & $-0.20(-0.99)$ & $0.05(0.31)$ \\
LnINFLt & $-0.11(-3.61)^{* *}$ & $0.01(0.64)$ & $-0.39(-3.3)^{* * *}$ & $0.13(1.18)$ & $-0.06(-0.78)$ \\
LnLoant & $-0.02(-0.95)$ & $0.03(4.32)^{* * *}$ & $-0.20(-2.48)^{* *}$ & $0.07(1.14)$ & $0.02(0.42)$ \\
LnHectt & $1.40(10.23)^{* * *}$ & $0.11(1.38)$ & $0.002(0.01)$ & $-1.05(-2.56)^{* *}$ & $1.46(6.09)^{* * *}$ \\
Dummy & $-0.19(-1.29)$ & $-0.24(-2.83)^{* * *}$ & $0.53(0.90)$ & $-1.69(-1.89)^{*}$ & $0.02(0.06)$ \\
R2 & 0.88 & 0.32 & 0.61 & 0.81 & 0.77 \\
F-cal & $65.78^{* * *}$ & $4.11^{* * *}$ & $13.80^{* * *}$ & $36.72^{* * *}$ & $29.39 * * *$ \\
DW-stat & 0.65 & 0.83 & 0.64 & 0.69 & 0.49
\end{tabular}

Note: Asterisks $* * *$ and $* * *$ represent $10 \%, 5 \%$ and $1 \%$ significance levels respectively. Variables are as defined in equation (4).

The results in Table 5 suggest that the variables in equations (4) specify for the 5 crop enterprises are co-integrated. The implication of the result is that an error correction specification would provide a better fit for equation (4) in all the 5 crop enterprises than would be the case without it.

Table 5. Engle-Granger Co-integration Regression test on Residuals generated from Equation 3 for Food Crop Enterprises

\begin{tabular}{|c|c|c|c|c|c|c|c|c|c|c|c|c|}
\hline \multirow[b]{3}{*}{$\begin{array}{l}\text { Residuals } \\
\text { (ECM) }\end{array}$} & \multicolumn{6}{|c|}{ ADF unit root test } & \multicolumn{6}{|c|}{ ADF-GLS unit root test } \\
\hline & \multicolumn{3}{|c|}{ With Trend } & \multicolumn{3}{|c|}{ Without Trend } & \multicolumn{3}{|c|}{ With Trend } & \multicolumn{3}{|c|}{ Without Trend } \\
\hline & level & 1st diff. & OT & level & 1st diff. & OT & level & 1 st diff. & OT & level & 1st diff. & OT \\
\hline Sorghum & $-3.63 * *$ & - & $1(0)$ & $-3.21 * *$ & - & $1(0)$ & $-3.33 *$ & - & $1(0)$ & $-3.26^{*}$ & - & $1(0)$ \\
\hline Cassava & $-4.36^{* *}$ & - & $1(0)$ & $-4.38^{* *}$ & - & $1(0)$ & $-3.34 *$ & - & $1(0)$ & $-3.19 *$ & - & $1(0)$ \\
\hline Rice & $-5.84^{* *}$ & - & $1(0)$ & $-5.89^{* *}$ & - & $1(0)$ & $-5.26^{* *}$ & - & $1(0)$ & $-4.59 * *$ & - & $1(0)$ \\
\hline Maize & $-9.69 * *$ & - & $1(0)$ & $-9.78 * *$ & - & $1(0)$ & $-9.87 * *$ & - & $1(0)$ & $-9.76^{* *}$ & - & $1(0)$ \\
\hline Yam & $-5.50 * *$ & - & $1(0)$ & $-5.28 * *$ & - & $1(0)$ & $-3.25^{*}$ & - & $1(0)$ & $-3.34^{*}$ & - & $1(0)$ \\
\hline $1 \%$ & -4.16 & & & -3.57 & & & -3.77 & & & & & \\
\hline $5 \%$ & -3.51 & & & -2.92 & & & -3.19 & & & & & \\
\hline
\end{tabular}

Note: OT means order of integration. Critical value (CV) is defined at $1 \%(* *)$ and $5 \%(*)$ probability levels.

\subsection{Selecting Optimal Lag-length for the Co-integrating Series}

To estimate the error correction model for each of the 5 food crop enterprises, optimal lag lengths were determined for the specify variables. The Akaike criterion (AIC), Schwarz Bayesian criterion (SBC) and 
Hannan- Quinn criterion (HQC) were used to select appropriate lag lengths for the cointegrating series. The test results as showed in Table 6 reveal that the optimum lag lengths appropriate for generating a more interpretable parsimonious ECM model for the specified variables were at the second lag for cassava, yam, rice and maize crop volatility equation. For sorghum the optimum lag length was at lag 3indicated by the asterisks among the information criteria.

Table 6. Optimal lag length of variables used in each equation in the analysis

\begin{tabular}{lllllll}
\hline Equations & lags & loglike & $\mathrm{p}(\mathrm{LR})$ & $\mathrm{AIC}$ & $\mathrm{SBC}$ & $\mathrm{HQC}$ \\
\hline \multirow{3}{*}{ Sorghum } & 1 & 50.72 & 0.00 & -1.94 & $-1.66^{*}$ & -1.84 \\
& 2 & 50.98 & 0.47 & -1.91 & -1.59 & -1.79 \\
& 3 & 54.25 & 0.01 & $-2.01^{*}$ & -1.64 & $-1.88^{*}$ \\
Rice & 1 & -31.43 & 0.00 & 1.67 & 1.95 & 1.78 \\
& 2 & -28.86 & 0.02 & $1.60^{*}$ & $1.92^{*}$ & $1.72^{*}$ \\
& 3 & -28.85 & 0.89 & 1.65 & 2.00 & 1.78 \\
& & & & & & \\
Cassava & 1 & 56.41 & 0.00 & -2.15 & $-1.87^{*}$ & -2.04 \\
& 2 & 57.98 & 0.08 & $-2.17^{*}$ & -1.86 & $-2.05^{*}$ \\
& 3 & 58.28 & 0.44 & -2.14 & -1.79 & -2.01 \\
& & & & & & \\
Maize & 1 & -50.85 & 0.00 & 2.52 & $2.79^{*}$ & $2.61^{*}$ \\
& 2 & -49.61 & 0.12 & $2.51^{*}$ & 2.82 & 2.62 \\
& 3 & -47.12 & 0.32 & 2.53 & 2.88 & 2.66 \\
& & & & & & \\
Yam & 1 & 11.09 & 0.00 & -0.18 & $0.10^{*}$ & -0.07 \\
& 2 & 12.98 & 0.05 & $-0.22^{*}$ & 0.10 & $-0.09^{*}$ \\
& 3 & 12.99 & 0.91 & -0.17 & 0.18 & -0.04 \\
\hline
\end{tabular}

Note: Asterisk means optimum lag length of series in each food crop volatility equation.

\subsection{Error Correction Model for Food Crop Volatility in Nigeria}

The results revealed that coefficients of the error correction term (ECM) was negative and statistically significant at $1 \%, 5 \%, 5 \%, 1 \%$ and $1 \%$ probability levels for cassava, sorghum, rice, and maize as well as yam equation respectively. The results validate the existence of a long-run equilibrium relationship among the time series in each of the food crop volatility equation, and also indicate that the food crop volatility in Nigeria is sensitive to the departure from it equilibrium value in the previous periods. The negative sign implies that, in the absence of variation in the independent variables, the model's deviation from the long run relation is corrected by increase in the dependant variable. For instance, the estimated coefficient of the $E C M_{t-1}$ is -0.13 for cassava suggesting that in the absence of changes in the explanatory variables, the deviation of the model from the long-term path is balanced by 13 per cent increase in cassava volatility per year. The diagnostic tests for the ECM model for each crop enterprise show satisfactory results. This implies that specify explanatory variables are important determinants of food crop output volatility in the country. The information criteria, RESET test and the normality tests for each crop enterprise confirm the correctness of Ordinary Least Squares estimation technique. 
Table 7. ECM estimates of Food crop output Volatility equation in Nigeria

\begin{tabular}{|c|c|c|c|c|c|}
\hline Variables & Cassava & Sorghum & Rice & Maize & Yam \\
\hline Constant & $-0.02(-1.17)$ & $0.02(1.217)$ & $-0.03(-0.29)$ & $-0.16(-1.03)$ & $-0.04(-0.73)$ \\
\hline$\Delta L n \operatorname{Lol}_{t-1}$ & $0.23(1.74)^{*}$ & $0.16(0.91)$ & $-0.04(-2.10)$ & $-0.04(-0.29)$ & $-0.22(-1.38)$ \\
\hline$\triangle L n P G D P_{t}$ & $-0.002(-0.08)$ & - & $0.36(1.83)^{*}$ & - & $0.01(0.12)$ \\
\hline$\triangle L n P G D P_{t-1}$ & - & $-0.05(1.65)^{*}$ & - & $0.12(0.42)$ & - \\
\hline$\triangle L n P G D P_{t-2}$ & - & - & - & - & - \\
\hline$\triangle L n P G D P_{t-3}$ & - & - & - & - & - \\
\hline$\triangle \operatorname{LnINFL}_{t}$ & - & $-0.04(-3.06) * * *$ & $-0.21(-2.43)^{* *}$ & $0.20(1.73)^{*}$ & $-0.024(-0.59)$ \\
\hline$\Delta \operatorname{LnINFL}_{t-1}$ & $-0.007(0.43)$ & - & - & $0.11(0.93)$ & - \\
\hline$\Delta \operatorname{LnINFL}_{t-2}$ & - & $-0.02(-1.58)$ & - & - & - \\
\hline$\Delta L n I N F L_{t-3}$ & - & - & - & - & - \\
\hline$\Delta \operatorname{LnLoan}_{t}$ & - & - & $-0.13(-1.80)^{*}$ & $0.05(0.59)$ & - \\
\hline$\Delta \operatorname{LnLoan}_{t-1}$ & - & - & - & - & - \\
\hline$\Delta \operatorname{LnLoan}_{t-2}$ & $0.004(0.48)$ & $-0.02(-2.19)^{* *}$ & - & $0.16(2.13)^{* *}$ & $0.021(0.82)$ \\
\hline$\Delta \operatorname{LnLoan}_{t-3}$ & - & $-0.016(-1.81)^{*}$ & - & - & - \\
\hline$\Delta L n C r o p H e c t_{t}$ & - & - & - & $-0.04(-0.85)$ & - \\
\hline$\Delta$ LnCropHect $t_{t-1}$ & $0.29(1.82)^{*}$ & $-0.28(-5.10) * * *$ & $-1.45(-3.70)^{* * *}$ & $-1.71(-3.50)^{* * *}$ & $0.25(2.29)^{* *}$ \\
\hline$\Delta L n C r o p H e c t_{t-2}$ & - & $-0.22(-4.29)^{* * *}$ & $-1.03(-2.37)^{* *}$ & - & - \\
\hline$\Delta L n C r o p H e c t_{t-3}$ & - & - & - & - & - \\
\hline Dummy & $0.07(2.59)^{* *}$ & $-0.018(0.89)$ & $-0.22(-1.69)^{*}$ & $-0.09(0.51)$ & $0.17(2.60)^{* *}$ \\
\hline$E C M_{t-1}$ & $-0.13(-2.68)^{* * *}$ & $-0.31(-2.60)^{* *}$ & $-0.29(-2.33)^{* *}$ & $-0.97(-3.92)^{* * *}$ & $-0.16(-2.71)^{* * *}$ \\
\hline$R^{2}$ & 0.49 & 0.63 & 0.59 & 0.79 & 0.48 \\
\hline$F$-cal & $5.28 * * *$ & $5.73 * * *$ & $6.64 * * *$ & $13.09 * *$ & $2.08 * *$ \\
\hline$D W$-stat & 2.00 & 1.99 & 2.22 & 2.02 & 1.92 \\
\hline Log-Likelihood & 58.94 & 66.62 & -23.07 & -35.27 & 11.19 \\
\hline Hannan-Quinn & -99.63 & -103.84 & 70.72 & 100.55 & --1.76 \\
\hline Schwarz C. & -90.46 & -91.37 & 81.01 & 113.13 & -7.39 \\
\hline Akaike C. & -105.11 & -111.25 & 65.56 & 93.01 & -7.21 \\
\hline RESET test & $4.97(0.030)^{* * *}$ & $4.97(0.03)^{* *}$ & $3.18(0.08)^{*}$ & $4.09(0.06)^{*}$ & $2.02(0.29)$ \\
\hline Normality test & $11.99(0.00) * * *$ & $5.73(0.05)^{* *}$ & $15.05(0.00)^{* * *}$ & $9.70(0.00) * * *$ & $6.45(0.00)^{* * *}$ \\
\hline
\end{tabular}

Note: Asterisks $*, * *$ and $* * *$ represent $10 \%, 5 \%$ and $1 \%$ significance levels respectively. Variables are as defined in equation (4).

\subsubsection{For Cassava Enterprise}

The result from the ECM model revealed that the lag coefficient of cassava output volatility was positive and statistically significant. This indicates that the past period of cassava output volatility affects the current period volatility. This is consistent with the ARCH model by Engle (1982), which postulates that volatility in the current period is related to its value in the previous period. The result also reveals that the harvested area of cassava had a positive correlation with cassava output volatility both in the long and short run. This means that in the short run and long run, increase in harvested area of land used for cassava cultivation would lead to increase in cassava output volatility in the country. In the similar way, cassava output volatility in the long run has a negative inelastic relationship with respect to inflation rate. This means that in the long run, increase in the inflation rate would lead to decrease in cassava output volatility in the country. The result is plausible because cassava and its derivatives is a normal food crop widely cultivated, consumes and is among the most affordable food commodities in Nigeria. Therefore increase in inflation rate would constrain demand of cassava and it derivatives as well as it production activities. In the same vein, the coefficient of liberalization policy period (Dummy) exerted a significant positive impact on cassava output volatility in the short run. This means that the liberalization policies directed towards food crop sector positively shifted the indices of cassava output volatility in the country. The result attests to the fact that cassava output volatility increases during period of liberalization in Nigeria. 


\subsubsection{For Sorghum Enterprise}

The coefficient of per capita real GDP (PGDP) is negative and statistically significant in both short and long run indicating that increase in (PGDP) dampens sorghum output volatility in the country. This implies that an increase in (PGDP) will lead to a fall in sorghum output volatility. This result could be attributed to the fact that sorghum is not widely consume among Nigerians. In addition, sorghum and its derivatives have some good substitutes and this make the demand for the commodity less competitive. This probably distorts sorghum production through reduction in investment in the sub sector. The inflation rate (INFL) in the short run is a significant negative determinant of sorghum output volatility in Nigeria. Fountas et al., (2006); Adreou et al., (2008); Narayan et al., (2009) and Chapsa et al., (2011) had reported similar relationship between inflation and volatility. The result indicates that in the short run increase in the nominal inflation rate reduces the tendency of increase sorghum output volatility in the country. The result might be explained by the fact that increase in inflation rate would increase the cost of production; the consequence will likely be lower output. In the short run, the impact of Loan guaranteed by ACGSF in the food crop sector and the harvested hectare of sorghum has significant negative influence on sorghum output volatility. The results could be due to the fact that ACGSF guaranteed sizable value of loans to sorghum farmers and the problem imposed by insufficient demand. However in the long run, the coefficient of loan became positive. The slope coefficient of liberalization policy period (Dummy) had a significant negative influence on the sorghum output volatility. This implies that the agricultural policies embedded in the liberalization period had significant negative influence on the sorghum output volatility. Alternatively, it implies that sorghum output volatility declines significantly during period of liberalization in Nigeria.

\subsubsection{For Rice Enterprise}

The result shows that the coefficients of inflation (INFL), PGDP, loan guaranteed by ACGSF and harvested area of land for rice as well as the liberalization period have significant negative impact on rice output volatility in the short run period. The liberalization policy package promoted massive importation of rice with limited attempt to increase efficiency of domestic producers. The policy gave small scale domestic producers unfavorable environment to compete with their large scale foreign producers. Also as inflation and PGDP increase the demand for cheap imported rice and it derivatives become cheaper and increase in expense to the domestic produce rice. This tendency distorted rice production and volatility in the short run. Surprisingly, the negative effect of inflation and loan guaranteed by ACGSF on rice output volatility persisted to the long run. However, the negative relationship between rice output volatility and inflation had been substantiated by Fountas et al., (2006); Adreou et al., (2008); Narayan et al., (2009) and Chapsa et al., (2011). The result could be linked to the fact that the rice sub- sector did not have competitive advantage as other crop enterprises. More so, rice demand in the country was simulated by consumer changing tastes and preference as regards cost and methods of preparation. In another way, the result could indicate the adverse impact of some of the macroeconomic policies on rice sub-sector in Nigeria.

\subsubsection{For Maize Enterprise}

The result revealed that the slope coefficient of inflation rate and loan guaranteed by ACSGSF in the food crop sub sector had a significant positive relationship with maize output volatility in the short run. This means that in the short run, increase in inflation rate would increase the output volatility of maize. This relationship corroborates the findings of Coulson and Robins (1985), but is contrary to the research report by Fountas et al., (2006); Adreou et al., (2008); Narayan et al., (2009) and Chapsa et al., (2011). The result could likely be explains by the fact that the Strategy Grain Reserves were set up in the country in 1988 to mop up excess production of grains. This policy provides incentives to farmers to produce more grains and also cushion the supply shortage during off season. In addition, increase in households and industrial consumption of maize and its derivatives boosted production and output volatility irrespective of increase in inflation rate in the country. The coefficients of harvested area of land for maize in both short and long run periods have negative impacts on maize output volatility in the country. However in the long run, the slope of liberalization policy era reduces maize output volatility probably due to inefficiency in implementing some of the policies designed to boost food crop output in the sub-sector. Esang (1973) and Muroi (1989) have reported similar result.

\subsubsection{For Yam Enterprise}

The ECM estimates reveal that the coefficients of harvested land area for yam and liberalization policy period were positive determinants of yam output volatility. This implies that increase in harvested area of land for yam would lead to increase in yam output volatility in the short run. The result with respect to harvested area of land for yam was replicated in the long run model. 


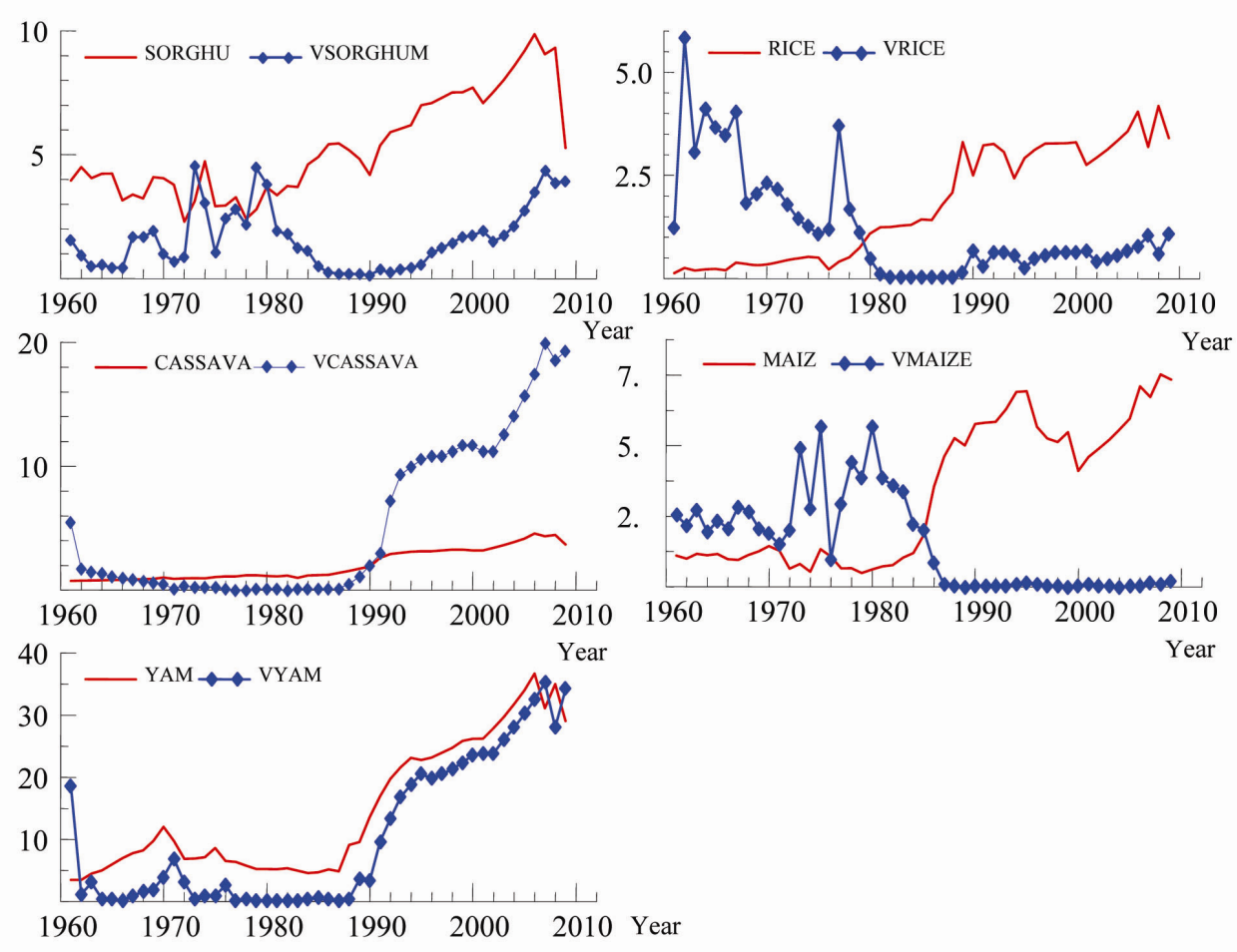

Figure 1. Annual food crops and their output and output volatility in Nigeria

(Note: Output axis for Sorghum $=* 10^{6}$ tons; Rice $=* 10^{6}$ t0ns; Cassava $=* 10^{7}$ tons; Maize $=* 10^{6}$ tons; and Yam $=* 10^{6}$. Volatility axis for Sorghum $=* 10^{-1}$; Cassava $=* 10^{-1}$ and Yam $=* 10^{-1}$ )

Figure 1 shows the graphical representation of selected food crop output and its respective GARCH $(1,1)$ volatility indices from 1961 to 2009. The result shows downward fluctuations in Rice and Maize enterprises especially during the period of liberalization (1986-2010). There was a remarkable variability in output of Rice, Maize and Sorghum enterprises during pre-liberalization period; whereas Yam and cassava enterprises exhibited minimal variability in output during pre-liberalization era in the country. On the other hand, Sorghum, Cassava and Yam enterprises showed gradual decline in their output during pre-liberalization period. On average, volatility of the selected food crop decreases during period of liberalization and increases during period of pre-liberalization era.

\section{Summary and Recommendations}

The study identifies significant factors that influence food crop output volatility in Nigeria. The major food crop consider were; cassava, sorghum, rice, maize and yam. Time series data derive from FAO data base for Nigeria and publications of CBN covering the period 1961 to 2010 were used in the study. Unit root on the specified variables confirm the presence of co-integration among the series implying the presence of a long-run equilibrium relationship. The long run and ECM models for the food crop output volatility were estimated using the specified variables. The ECM error term for each of the crop enterprises had the appropriate sign and was statistically significant at various probability levels indicating a quick convergence to equilibrium in each period, with intermediate adjustments captured by the differenced terms. The findings show that inflation rate, per capita real GDP, harvested hectare of food crops, loan guaranteed by ACGSF in the food crop sub-sector and agricultural policy content of the liberalization period interact in each period to re-establish the long-run equilibrium in food crop output volatility following a short-run random disturbance in the individual food crop output volatility equation in the Nigeria's economy. The empirical results for the long run and short run food crop output volatility equations revealed mixed and inconsistent impacts of the explanatory variables on food crop output volatility in the country. The study also discovers that on aggregate, food crop output volatility decreases in the liberalization policy period and increases during pre-liberalization era.

The study however advocates for appropriate short and long term policy packages that should addressed appropriately the identified significant macroeconomic shifters of food crop output volatility in the Nigeria's economy. Emphasis should also be channel towards strengthening the institutional framework responsible for 
disbursement of credit and increase the value of loan disbursed to food crop sector in the country. Also effort should be directed towards improving the quality of land allocated to food crop sub sector by adopting appropriate soil management technique. Furthermore, food crop agricultural policies in the liberalization policy package should be design in the short term basis and use as a basis for altering food crop output in Nigeria.

\section{References}

Abayomi, Y. O. (1992). The agricultural sector in Nigeria; the way forward, Central Bank of Nigeria Bullion, Lagos, 21(3), 11-24.

Adeel Malik, A., \& Jonathan, R. W. Temple. (2006). The Geography of Output Volatility. A seminar presented at the University of Oxford.

Adekanye, T. O., Otitolaiye, J. O., \& Opaluwa, H. I. (2009). Food and Agricultural Production in Nigeria: Some Empirical Considerations for Engendering Economic Policy for Africa. Paper presentation at the IAFFE Conference on Feminist Economics, Boston, Massachusetts, USA, 26-28.

Agenor, P. R., McDermott, C. J., \& Prasad, E. S. (2000). Macroeconomic fluctuations in developing countries: some stylized facts. World Bank Economic Review, 14(2), 251-285. http://dx.doi.org/10.1093/wber/14.2.251

Akpan, S. B. (2010). Encouraging Youth Involvement in Agricultural Production and Processing in Nigeria. Policy Note No. 29: International Food Policy Research Institute, Washington, D.C.

Akpan, S. B. (2012).Analysis of food crop output volatility in Agricultural policy programme regimes in Nigeria. Developing Country Studies, 2(1), 28-35.

Akpan, S. B., \& Udoh, E. J. (2009a). Relative Price Variability and Inflation in grain sub- sector in Nigeria. Global Journal of Agricultural Sciences, 8(2), 147-151.

Akpan, S. B., \& Udoh, E. J. (2009b). Estimating Grain Relative Price Variability and Inflation Rate Movement in Different Agricultural Policy Regimes in Nigeria. Humanity and Social Sciences Journal, 4(2), 107-113.

Andreou, E., Pelloni, A., \& Sensier M. (2008). Is volatility good for growth? Evidence from the G7.Centre for Growth and Business Cycle Research, Discussion Paper Series No. 97, University of Manchester.

Anyanwu, J. C., Oyefusi, A., Oaikhenan, H., \& Dimowo, F. A. (1997). The Structure of the Nigerian Economy (1960-1997). Onitsha Joanee Educational Publisher.

Bollerslev, T. (1986). Generalized Autoregressive Conditional Hetroscedasticity. Journalof Econometrics, 31, 307-327. http://dx.doi.org/10.1016/0304-4076(86)90063-1

Central Bank of Nigeria. (2010). Statistical Bulletin Central Bank of Nigeria.

Chigbu U. E. (2005). Agriculture as the only savior to Nigeria dyeing economy. Retrieved from $12^{\text {th }}$ July 2005 $\mathrm{http}: / / \mathrm{www}$.nigerianvillagesquare.com

Coulson, E., \& Robins, R. (1985) Aggregate economic activity and the variance of inflation: another look, Economics Letters, 17, 71-75. http://dx.doi.org/10.1016/0165-1765(85)90130-2

Crains, S. J., \& Lee, J. H. (1996). Volatility in Wheat spot and future Markets, 1950- 1993: government farm program, seasonality and causality. Journal of finance, 51, 325-343.

Essang, S. M. (1973). The 'Land Surplus' Notion and Nigerian agricultural development policy.

Federal Republic of Nigeria. (2000). Obasanjo's Economic Direction 1995-2003. Office of the Honourable Minister for Economic Matters, Abuja, Nigeria.

Federal Republic of Nigeria. (2000). Obasanjo's Economic Direction 1995-2003. Office of the Honourable Minister for Economic Matters, Abuja, Nigeria.

Fountas, S., Karanasos, M., \& Kim, J. (2006). Inflation uncertainty, output growth uncertainty, and macroeconomic performance. Oxford Bulletin of Economics and Statistics, 68, 319-343. http://dx.doi.org/10.1111/j.1468-0084.2006.00164.x

Fountas, S., \& Karanasos, M. (2007). Inflation, output growth, and nominal and real uncertainty: empirical evidence for the G7. Journal of International Money and Finance, 26, 229-250. http://dx.doi.org/10.1016/j.jimonfin.2006.10.006

Garba, P. K. (2000). An analysis of the implementation andstability of Nigerian agricultural policies, 1970-1993. AERC Research Paper 101African Economic Research Consortium, Nairobi. 
Ghebrechristos, Y. E. (2004). The impact of exchange rate volatility on export: A case study of South Africa's citrus fruit export. MSc Agric Thesis. Department of Agricultural Economics, University of the Free State.

Government of Nigeria. (2004). Meeting Every Body's NEEDS; National Economic Empowerment and Development Strategy, National Planning Commission, Abuja Nigeria.

Government of Nigeria. (2006). National Accounting Survey, National Bureau of Statistics, Abuja Nigeria.

Gujarati, D. N. (2004). Basic Econometrics.Tata McGraw-Hill publishing company limited. New Delhi, India.

Heifner, R., \& Kinoshita, R. (1994). Differences among commodities in real price variability and drift. Journal of Agricultural Economics Research, 45(3), 10-20.

Hendry, D. F. (1995). Dynamic Econometrics, Oxford: Oxford University Press. http://dx.doi.org/10.1093/0198283164.001.0001

Izuchukwu, O. (2011). Analysis of the Contribution of Agricultural Sector on the Nigerian Economic Development. World Review of Business Research, 1(1). 191-200.

Jansen, D. (1989). Does inflation uncertainty affects output growth? Further evidence. Federal Reserve Bank of St. Louis Review, 71, 43-54.

Jeter, H. F. (2004). How to revive Nigeria's agricultural sector. The vanguard Lagos. Retrieved on 22 nd July2004 from http://africa.com/stories/200403040476.html

Jordaan, H., Grové, B., Joosteand, A., \& Alemu, Z. G. (2007). Measuring the Price Volatility of Certain Field Crops in South Africa using the ARCH/GARCH Approach. Agrekon, 46(3).

Malik, A., \& Jonathan, R. W. (2009). The Geography of Output Volatility. Journal of Dev. Econs., 90(2), 163-178. http://dx.doi.org/10.1016/j.jdeveco.2008.10.003

Moledina, A. A, Roe, T. L., \& Shane, M. (2003). Measurement of commodity price volatility and the welfare consequences of eliminating volatility. Working Paper at the Economic Development Centre, University of Minnesota.

Muroi, Y. (1989). Economic crisis anddevelopment policies in African states in 1980s. Institute of Developing Economies(I.D. E.), Tokyo.

Narayan, P. K., Narayan, S., \& Smyth, R. (2009). Understanding the inflation-output nexus for China. China Economic Review, 20, 82-90. http://dx.doi.org/10.1016/j.chieco.2008.10.012

Nigerian National planning Commission. (2004). Meeting Everyone's Needs- National Economic Empowerment and Development Strategy Nigerian National Planning Commission, Abuja.

Rodale, Robert. (1988). Agricultural Systems: The Importance of Sustainability in National Forum, summer.

Sanusi, L. S. (2010). Growth Prospects for the Nigerian Economy Convocation Lecture delivered at the Igbinedion University Eighth Convocation Ceremony, Okada, Edo State, November 26.

Titilola, S. O. (1987). The Impact of the Structural Adjustment Program (SAP) on the Agricultural and Rural Economy of Nigeria in Structural Adjustment Program in a Developing Economy: The case of Nigeria by Adedotun O. Phillips and Eddy C. Ndekwu (Eds). (NISER)

Udoh, E. J., \& Akpan, S. B. (2007). Estimating Exportable Tree Crop Relative Price Variability and Inflation Movement under Different Policy Regimes in Nigeria. European Journal of Social Science, 5(2), 17-26.

Ukoha, O. O. (2007). Relative Price Variability and Inflation: Evidence from the Agricultural Sector in Nigeria. AERC Research Paper 171 African Economic Research Consortium, Nairobi.

Xanthippi Chapsa, X., Constantinos, K., \& Nikolaos, T. (2011). Dynamic Linkages between Output Growth and Macroeconomic Volatility: Evidence using Greek Data. Int. J. Eco. Res., 2(1), 152-165.

Yang. J., Besslev, D. A., \& Leatham, D. J. (2001). Asset storability and price discovery of commodity futures markets: a new look. Journal of Future Markets, 21, 279-300. http://dx.doi.org/10.1002/1096-9934(200103)21:3<279::AID-FUT5>3.0.CO;2-L

Young, E., \& Shields, D. A. (1996). OVERVIEW: FAIR Act frames farm policy for 7 years, Agricultural outlook (USDA), April 1-4. 